\title{
Arrest and Police Remand Issue of Top Jamaat Leaders in Bangladesh: Under the Guise of Hurting the Religious Sentiments of Muslims
}

\author{
Dr. Md. Abdul Jalil \\ Associate Professor \\ Faculty of Economics and Management \\ International Islamic University Malaysia (IIUM), Malaysia \\ E-mail: abd_jalil2@yahoo.com, abduljalil@iium.edu.my \\ Muhammad Khalilur Rahman \\ Master of Finance Student \\ Faculty of Economics and Management \\ International Islamic University Malaysia, Malaysia \\ E-mail: abd_khalil2@yahoo.com
}

\begin{abstract}
Bangladesh is a country which is located at the Southern part of the globe, Southern side of India and on the bank of the Bay-of-Bengal. It was formerly a part of Pakistan but Bangladesh is now an independent country. On 16 December 1971, Bangladesh became separated after nine months of a bloody liberation/civil war with Pakistan. The main objective of the liberation was to obtain independence so as the development of the country can be fully implemented in all aspects, as far as possible, in order to meet the needs of people who have been long ignored by the former masters. But the objectives of indepence were not that easily fulfilled because in 1972 and after numerous democratic parties were established in Bangladesh, but they still could not work together peacefully as joint partners for the development of the country. The political party leaders still have the mentality of their former masters which they have unconsciously inherited in terms of jealousy and feeling of distrust amongst themselves subsequently developing into open hostility and bloody fighting among themselves on minor differences of political ideology and policy. This paper focuses on the current scenario of social-political situation in Bangladesh.
\end{abstract}

Keywords: Politics in Bangladesh, False and concocted criminal suit, Political vendetta, War crimes, War crimes tribunal, Legality of war crimes law, Fair and impartial investigation, Fair and impartial trial, Political persecution of Jamaat leaders

\section{Introduction}

On 17 March, 2010, in a meeting of Bangladesh Jamaat-e-Islam (better known as Jamaat), the Secretary of Dhaka City of Jamaat gave an introductory speech in which he said that this world was created billions of years ago by Allah (God) and Allah (God) sent many Prophets from time to time to teach people and to bring them back to the right path of religious practice as they had all along gone astray over the passage of time. Examples of some of the latest Prophets are Moses, Jesus Christ and Muhammad. Muhammad (peace be upon him) as the last Prophet as there will be no more Prophet in this world after him (Al-Quran, Surah Ahzab 33:40; Sahih Muslim; Sahih Bukhari). Narrated by Abu Hurairah, prophet Muhammad (peace be upon him) said the Israelis used to be ruled and guided by prophets sent by Allah from time to time and whenever a prophet died another would take over his place. Prophet Muhammad also said in this hadis: "There will be no prophet after me, but there will be Khalifas (rulers, head of states) who will increase in number." (Sahih Bukhari, Hadis No. 661).

All these Prophets called upon their people to conduct their way of life as laid down by Allah (God) but their people rejected them, conspired against them, beat them, drove them out from the city/country, and even some of the prophets were killed by their people (the Bible states that prophet Jesus Christ was crucified by the Jews). Some of the prophets were killed by their people and this has been mentioned in the Bible and the Quran (Bible: Luke 3:19-20; Mathew 14: 3-12, 21: 23-27; Al-Quran: 2:61, 91; 3: 112). Prophet Muhammad was no exception 
in this sort of treatment as he was driven out of Makkah, his birth place, to Madinah in which the incident has been fully narrated in the Quran and hadis.

According to Kalz, Jochen, the Jews had killed many prophets sent to them by Allah from time to time. According to Askar, prophets were opposed, persecuted and killed by their people. Jewish community killed some of the prophets such as Zakaria and his on John (Yahya). Zakaria was cut in half and his son John's (Yahya) head was cut off while he was praying (Askar, 2006). They also attempted to kill prophet Moses, his brother, a prophet named Aaron (Harun) and Jesus Christ (Isa). The Kafirs (disbelievers) in Makkah, Saudi Arabia, also conspired to kill prophet Muhammad (Askar, 2006).

The secretary of Dhaka City of Jamaat, Mr. Rafiqul Islam said in his speech that Jamaat is calling people to lead their way of lifestyle as laid down by Allah (God), by following the true teaching of Prophet Muhammad (peace be upon him) who at that point of time was not accepted by the people at the beginning in Makkah, Saudi Arabia. People made conspiracy against him and started spreading false propaganda against him. Gradually they started oppressing him. They had beaten him on several occasions and severely injured him on several incidents and as a last resort they planned to kill him.

Mr. Rafiqul Islam said in his speech that similar false propaganda and conspiracy are being made against Jammat and its President Matiur Rahman Nizami. He said in that meeting that the present government Awami League (AL) is conspiring against and oppressing Jamaat and its President in the same way as the Makkah people conspired against and oppressed Prophet Muhammad. He wanted to say that if any social or political group were calling upon the people to follow the way of life as established by Allah in the same way as Prophet Muhammad called upon his people to the path of righteousness as laid down by Allah, similar conspiracy and oppression will be inflicted against that group and its leaders, Islamic history says so. He actually did not compare Jamaat leader Nizami with Prophet Muhammad having similar moral and religious qualities, but one person had sued four top Jamaat leaders (who were present in that meeting) to court for hurting the religious sentiments of the Muslims in Bangladesh by comparing Jamaat President Nizami with prophet Muhammad (The Daily New Age, 1 July, 2010; The Daily Sangram, 1 July, 2010). It is known to the people of Bangladesh that this case was a political conspiracy of the present AL government and some other quarters.

Based on this case on 29 June 2010, three top Jamaat leaders: Jamaat President Nizami, Vice-president Saydee and Secretary General Mujahid were arrested on the ground of 'hurting the religious sentiments' of Muslims in Bangladesh. The court in Bangladesh granted them bail as the case was not serious, but Awami League (AL) government wanted them arrested on other five false charges and concocted cases and brought them on police remand for 16 days in each case consecutively. After consecutive 19 days remand were over they were again taken on remand for another 3 days for another false charge. The lawyers of the accused contested that putting suspected people on remand consecutively of these old political leaders for so many days on false charges is a cruel and inhuman barbaric practice without due civilized consideration. They were not allowed to talk to their lawyers during remand and they were not given medical treatment although they were sick due to different types of diseases. Later on 19 July 2010, two more Jamaat top leaders were arrested on similar five false cases and were taken to police remand for 16 days for each of them. This paper narrates the situation of arrest, remand and oppression on the top Jamaat leaders since 29 June 2010 in Bangladesh for more than one month. The Jamaat leaders are still on remand on different false cases.

Descriptive and analytical research methodology has been applied in this paper to explain the sociopolitical situation in Bangladesh since its independence in 1971. This research is very important as the world people should know the abhorrent socio-political condition in Bangladesh so that the world community, especially the US, the UN and human rights organizations can put pressure on AL government to rule Bangladesh following democratic and human rights values provided in the Universal Declaration of Human Rights (UN) and other international conventions related to human and political rights. It should rule the country fairly towards development and punish the criminals without any discrimination such as based on political party identity and so on.

\section{Brief political history of Jamaat}

Bangldesh Jamaat-e-Islami (Jamaat) is one of the oldest parties in the sub-continent. It was established in British India in 1941. Jamaat started its work in Bangladesh in the 1950s when it was a part of Pakistan (East Pakistan). Jamaat is a moderate Islamic political party that believes in democracy, human rights and is committed to upholding the rule of law. Jamaat wants to establish a just society through democratic process, because in Islam no one has the right to lead people unless he or she is an elected representative of the people (BJI, 2008). In other words, Islamic political philosophy fully supports democracy, but the elected representatives in Islamic 
democracy are answerable to both the people in this world and to Allah (God) in the hereafter. This philosophy of democracy in Islam makes it unique and that for this particular reason the Prophet Muhammad and after his death, the four famous Khalifas (Head of united Muslims States) became the most successful world leaders in ensuring peace, religious harmony, dignity of human being as well as economic development. Khalifa Umar ruled half of the world peacefully and achieved significant progress and development in all the countries under his rule. Its truth is the evidence of Islamic history during the rule of prophet Muhammad and after his death during the rule of four famous Khalifas.

This is the main reason for Jamaat to follow the democratic path for more than half a century since its establishment in India in 1941. It had participated in almost all the national and local elections. To attain its objectives, Jamaat has never resorted to violence or unconstitutional or undemocratic means. It has always abided by the laws of the country and in the face of extreme provocation and political repression from the ruling government, it observed patience and pursued legal means through court of law to defend itself. For example, in January 1964 Jamaat was outlawed by the then government of Pakistan. The decision of the government was challenged in the court and finally, the Supreme Court of Pakistan presided over by the then Chief Justice A.R. Cornelius declared the government's action of outlawing Jamaat unlawful (Sayiid Abul A'la Mawdudi and Others Vs.The Govt. of Pakistan and Others (1964).

Similarly in 1973, the AL government, by a notification disqualified Professor Golam Azam, the former President (Ameer) of Jamaat, from being a citizen of Bangladesh for his role against the separation of Bangladesh from Pakistan. Hence, he did not have Bangladesh citizenship for 22 years although he was born in Bangladesh and involved in politics in Bangladesh for a long time. After 22 years of having no citizenship in Bangladesh, Professor Golam Azam challenged the order of the AL government of Bangladesh in the High Court. After hearing the case both the High Court Division and later the Appellate Division of the Supreme Court of Bangladesh declared the AL government's decision to proscribe his citizenship was unlawful. Thus Professor Golam Azam, the former President of Jamaat, reinstituted his birth right of citizenship through the court of law (Professor Golam Azam Vs. Bangladesh, 1994 and 1995).

Jamaat got 20 Parliamentary seats in the 2001 national election and made a coalition government with BNP. The coalition government ruled Bangladesh between 2001 to 2006. Jamaat got two ministries in the cabinet; Ministry of Industry and Ministry of Social Welfare. Jamaat President Motiur Rahman Nizami became the Minister of Industry and Jamaat Secretary General, Ali Ahsan M. Mujahid became the Minister of Social Welfare. Both of them led their individual ministry successfully and achieved satisfactory progress and development in their respective ministry which is known to the people of Bangladesh. Motiur Rahman Nizami got the greatest amount of foreign investment during his ministerial tenure and he also achieved the highest rate of GDP growth in the industry sector which broke the last fifteen years' foreign investment record of Bangladesh. Even though Bangladesh is known as one of the most corrupt country in the world, these two ministers were incorruptibly clean. They were not involved in any bribery incidence. Welfare Minister Mr. Mujahid expressly declared to the media during the Care-taker government in 2008 that both Nizami and Mujahid were not involved in any corruption even of one taka (Bangladesh currency) value.

Jamaat sources say that there is an abysmal whirlpool of conspiracy is now underway nationally and internationally against Jamaat. The conspirators do not dare to confront Jamaat in a straightforward manner as they do not have a beautiful and harmonious ideology that Islamic political philosophy has. That is why they are adopting all sorts of devious ways to suppress Islam and Jamaat. The Central Executive Committee of Jamaat recently called upon all Islamic organizations, religious leaders and scholars, students, teachers, lawyers, businessmen, workers, peasants, and people in all strata of national life to come forward irrespective of differences of ideology and political party affiliations to foil the conspiracy of AL government against Jamaat (Daily Sangram, 22 July 2010).

\section{Facts of the alleged offence}

As stated in the introduction that a petition was filed on March 21, 2010 with Metropolitan Magistrates Court accusing four top Jamaat leaders for hurting religious sentiments of the Muslims. In the petition, it was alleged that Jamaat leader Rafiqul Islam Khan, the Secretary of Dhaka City at a discussion in Dhaka on March 17, 2010 compared Nizami with the Prophet Muhammad (The Daily New Age, $1^{\text {st }}$ July, 2010), but Jamaat leaders denied the charge saying that it was concocted and a politically motivated charge (The Daily New Age, $1^{\text {st }}$ July, 2010).

\section{Mistreatment and oppression of Jammat leaders in remand}

On 27 June 2010, Bangladesh Nationalist Party (BNP), the largest political party in Bangaladesh staged nationwide strike in protest of arrest and oppression on opposition party supporters and leaders. Jamaat and its 
branch organization Shibir wholeheartedly supported and participated in this nationwide strike which was successfully completed without any incident of vandalism. It was a peaceful strike to protest against the AL government for its oppression on opposition parties and numerous other negative acts and international agreements which went against the national interest of Bangladesh and its people. It also failed to provide adequate electricity, gas and water to the people of Bangladesh since it came to power in January 2009. The weather is very hot in Bangladesh now, so the people are suffering severely due to inadequate supply of electricity, water and gas.

Instead of solving these fundamental problems, the AL government undertook many negative acts which went against the national interest and national security of Bangladesh as mentioned above. When the opposition criticized the AL government mismanagement of its governance, instead of mending the errors it started oppressing them. The AL government ordered the police to prohibit all types of gathering in protest against the government oppression of the opposition leaders. This was the main reason of the 27th June 2010 nationwide strike in Bangladesh. During the strike, the Sattro League (a student branch organization of AL) was also involved in beating up the opposition leaders in tacit co-operation with the police. Many people became seriously injured due to this joint beating incident the by police and the Sattro League (Siddiqui, 2010). People of Bangladesh thought that it was really inhuman as the AL government used its party members to beat opposition party leaders when they peacefully protested against the government's negative and oppressive activities.

On 29 June 2010, BNP and Jamaat called for a nationwide strike from morning to evening in protest against the arrest and oppression of the opposition political leaders on the 27 June 2010. The strike was peaceful and people from all corners in the country supported the strike with enthusiasm to show their 'no' support for the AL government (Siddiqui, 2010). In this strike, AL government again used the police and Satro League to beat up and arrest the opposition supporters and leaders. The AL government was furious because the Jamaat party supported and participated in the strikes called by BNP on 27 and 29 June 2010. As a result of this political holocaust, the police arrested around 500 Jamaat leaders and their supporters on 29 and 30 June 2010, and cruelly beat them and brought them on police remand on false charges.

According to the 1st July 2010 newspaper report, three top Jamaat leaders were arrested on 29 June 2010 and they were taken to court on 30 June 2010. In the Chief Metropolitan Magistrates Court (CMM court), police and Awami League (AL) government lawyers demanded remand for 20 days on all five cases for each leader but the court granted 16 days remand for each of the three Jamaat top leaders. The case was related to "hurting the religious sentiments of Muslims in Bangladesh" as mentioned above. Police arrested more than 500 Jamaat and Shibir (a student branch organization of Jamaat) leaders from all over the country on 29 and 30 June. It is to be noted as of 5 August 2010 around 5000 Jamaat leaders have been arrested on different false cases and they are put in jail. At the beginning on 29 June 2010 three top Jamaat leaders were arrested on the ground of hurting religious sentiment of the Muslims in Bangladesh, but on the next day when they were produced in the CMM court they were given bail as it was a bailable case and the lawyers argued in the court that it was not a serious case. However, the police said they were arrested under other five false charges which were filed against them based on political vendetta (The Daily Sangram, 1 July, 2010). BNP Secretary General pointed out that the Jamaat top leaders had been arrested in one case, and remanded for others cases. He termed the strategy of the AL government as 'undemocratic' and 'illegal'.

It is widely known to the people of Bangladesh that this arrest and police remand was to oppress the top Jamaat leaders as a means of political revenge because the AL government has miserably failed to face the Jamaat party with better political ideology as the Jamaat party had previously demonstrated. The other reason of the AL government to arrest the Jamaat party leaders and police remand on many false charges was to destroy the Jamaat party as a viable and progressive political organization without any genuinely and legally valid reason. On other cases the Jamaat party was accused to have been involved in obstructing the police in discharging their duties with the intention of destabilizing the political climate in Bangladesh. As a result of this display of political stupidity of the AL government, the Jamaat president Nizami, Jamaat Vice-President Saydee and Secretary General, Mujahid were shown arrested in another case at the Pallabi police station which was filed on January 25, 2008 accusing them and seven others of killing 344 people during the liberation war in 1971. The three top Jamaat leaders were also shown arrested in a case of killing Bangladesh Satro league activist Faruk Hossain at Rajshahi University in February 2010. Another case was filed against them regarding vandalism and arson during nationwide peaceful strike by all the opposition parties in Bangladesh on 27 June 2010 as mentioned earlier. (The Daily Sangram, 1 July, 2010; the Daily Star, 1 July, 2010). 
According to Jamaat sources, all these cases are false and politically devised to oppress the Jamaat leaders with the ultimate aim of banning this popularly supported and democratically established political party. At present the Jamaat Party has 30 million supporters out of 150 million people in Bangladesh. This is a huge number of support for Jamaat in Bangladesh and the AL government is very nervous and politically displeased of its popularity. Jamaat leaders Motiur Rahman Nizami, Ali Ahsan Mohammad Mojahid and Delwar Hossain Sayedee denied their involvement with the subversive activities during the June 27 'strike' when they were in police remand (Police report, 2 July 2010, The Daily Star).

Bangladesh Nationalist Party (BNP) is one of the largest political parties in Bangladesh and it came to power three times after the independence of Bangladesh in 1971. This party has declared its undivided support for the arrested Jamaat leaders. BNP Secretary General Khandaker Delwar Hossain on 2 July 2010 said that his party would remain beside Jamaat and extend its support to the party programs. He said, "As Jammat has supported us so we will also help the party to carry on its programs," Delwar told this in a press briefing after a joint-meeting of the party and its front organizations at Naya Paltan, Dhaka, the party central office (Delwar, The Daily Star, 2 July, 2010).

BNP Secretary General, Delwar also said Jamaat became the victim of the government's blueprint. BNP Chairperson Khaleda Zia on 1 July 2010 demanded immediate release of top Jamaat leaders and termed their arrests as "a heinous example of political repression in an autocratic manner" (The Daily Star, 2 July 2010). She issued a written statement after the party's standing committee meeting on 1 July 2010. In this written statement she condemned the arrests of top Jamaat leaders and urged the government to keep away from repressing the opposition parties (The Daily Star, 2 July 2010).

Amnesty International (AI) also criticized the AL government for oppression on Jamaat and BNP leaders. Amnesty International (AI) on 2 July 2010 said that the security forces had conducted excessive raids on the house of BNP leader Mirza Abbas during June 27 countrywide 'strike'. In a statement, the London-based human rights watchdog strongly criticized the government's highhanded approach against the opposition parties (AI, 3 July 2010).

Khandaker Delwar called upon the government not to obstruct their July 7 countrywide 'human chain' which was announced to demand release of the leaders and workers of the party who were arrested during 27 and 29 June 2010 strike. Khandaker Delwar Hossain, the Secretary General of BNP presided over the joint-meeting which was attended by senior leaders of the party and presidents and general secretaries of its front and associate organizations (New Nation, 3 July, 2010).

As the AL government has been arresting and oppressing the opposition political party leaders, the BNP staged a nationwide 'human chain' program on 7 July 2010. The human chain program was peaceful and the people of Bangladesh participated in this human chain program at their own accord. But police obstructed the main opposition political party BNP's nationwide human chain program and beat up the people who participated and gathered for the program. This obstruction and beating of people triggered sporadic clashes, chases and counter chases between law enforcers and opposition activists that left one person dead. As the human chain program was a peaceful political rally, the AL government should not have obstructed its peaceful street demonstration and had no cause or legal valid reason to have beaten up the BNP party members including their leaders. One person died during this human chain program as a result of cruel police beating. It was a very sad news and a clear violation of human rights (The Daily Star, 8 July, 2010).

The famous and senior lawyer in Bangldesh, Barrister Rafiqul Huq gave an interview with ATN Bangla television and expressed his views that the arrest of Jammat leaders and taking them to remand is totally a political gimmick as the charges against them were unfounded without any watertight proof. Normally they might be oppressed during remand just to obtain false confession on charges because their oppressors may have long left their Islamic faith. This form of oppression is tantamount to human rights violation as there was no valid strong case against the Jamaat leaders. The charge for which Jamaat leaders were arrested was firstly, a weak suit and they got a bail in that suit but the AL government added other five political suits so as to enable them to continue detaining them and demanded for police remand. (Ilias, 2010).

It is actually very surprising indeed that the police in Bangladesh had expressly without reservation said that they had purposefully attacked and prevented the 27 June 'Strike' and 7 July 'human chain' program on the order of the AL government. (Siddiqui, 2010). It means that the AL party was in sheer disregard of sustainable civil law and unreservedly acted against democracy and human rights of the people of Bangladesh. It is using the police force to pit against innocent opposition leaders and supporters and using the police force against their will to 
carry out the government orders to crack down on opposition parties in Bangladesh without any sustainable legal valid reason (Siddiqui, 2010).

The former Advisor to Care-taker Government of Bangladesh Dr. Akbar Ali told Somokal, a Daily newspaper in Bangladesh that it was indeed very sad for the Bangladeshi people that the country was again approaching a mayhem on the brink of a holocaust. It would not be beneficial for the people and the country as such an ungovernable chaotic political situation was dangerous for the survival of democracy in Bangladesh. He advised the government and the opposition parties to avoid frenzied way of executing politics and to take effective steps to maintain peaceful and friendly situation for the interest of democracy and the country. (Akbar, 2010).

The Bangladeshi people all over the world are very sad for the total failure of the AL government to lead the country towards peace, security and development but instead oppressing the opposition party leaders and supporters cruelly. For this reason the Bangladeshi origin as UK citizens have filed a written petition to the Prime Minister of Bangladesh to stop the oppression system on the opposition and to undertake development projects to develop the country to solve the electricity, water, gas shortage problems and to take effective measures to stop increase in price of daily necessities in the country. Below is a copy of a petition by UK citizens to the Prime Minister of Bangladesh to stop oppression on opposition party leaders and mass arrest, cruel treatment in police remand etc. in the interest of the peaceful environment in the country (Petition to Prime Minister, 2010. See, http://www.petitiononline.com/u080710k/).

To: Prime Minister's Office, Bangladesh

Her Excellency

Sheikh Hasina Wazed

Prime Minister

Peoples Republic of Bangladesh

Your Excellency,

We write to bring to your attention our concerns and complaints, as non-resident Bangladeshis living in the United Kingdom, with regards to recent events that have taken place in Bangladesh. The past week has witnessed the unjustified and politically motivated arrest and imprisonment of leaders from Bangladesh Jamaat Islami under a system of law that is both draconian and prejudiced. The trumped up charges brought against Maulana Nizami, Jamaat Chief and a former cabinet minister and MP; Mr. Ali Ahsan Mohammad Mujahid, Jamaat Secretary General and a former cabinet minister; and Maulana Sydee, Jamaat central executive committee member and a former MP, are farcical and a gross abuse of government power for political profiteering.

These events have made the government's intentions manifestly clear. The nature of the cases renders it impossible for any thinking individual to identify any truth in the claims levied, nor to accept the legality of the government's intervention and actions. Both the common people and world leaders will only interpret these steps as evidence of the Bangladeshi government plunging the country into an authoritarian regime.

Given recent trends in Bangladesh, with the clampdown upon freedom of the press and political thought, human rights violations in contravention of both international laws and that of Bangladesh itself and the effective elimination of an independent judiciary, we are concerned that the current government has indeed descended into an autocratic and dictatorial regime. It is greatly worrying to see that in the last 18 months the $\mathrm{AL}$ government orchestrated actions that have included:

- Compromising the independence of the judiciary by appointing incompetent and partisan Judges to the High Court division of the Supreme Court of Bangladesh;

- Re-organizing the judicial benches with active pro-government party political supporters in the most important writ and bail benches along with the Appellate division by superseding senior judges to appoint less competent Judges in direct contravention to the customs of the country's highest judiciary; and

- Conducting regular undue interventions into judicial decisions through the politically appointed Attorney General's office and that of Public Prosecutors,'

- Closing down the respected opposition daily 'Amardesh' newspaper and arrested its editor who has now testified to torture during remand in police custody for weeks;

- Ordering the closure of Channel One, a popular TV channel, by an executive decision of the Ministry of Information; 
- Cancelled the license of another TV channel, Zamuna TV, to start their broadcasting;

- Stopped the most popular talk shows on various TV channels;

- Issued license to another 10 new TV channels to their own party leaders and businessmen;

- Arrested former Secretary of the State, Mr Shomsher Mubin Chowdhury, an adviser to the chairperson of BNP who is now in police remand along with former Mayor of Dhaka City Corporation. A number of opposition MPs were also arrested from the opposition rallies along with several other opposition activists;

The government is bringing disrepute and international embarrassment to our beloved nation through their thoughtless and reckless actions. Our already fragile democracy will crumble if the government continues to act with such impunity in pursuit of political supremacy. Our country needs stability, good governance, strong economic policies, improvement to health, social welfare and infrastructure as well as education suitable for the 21 st century. These are the matters of importance which, if invested in well, will improve the condition of our impoverished nation. The government's current stance and behavior will only hamper progress of our nation.

For all of us living here in the UK, democracy is open and available for us to express our views and exercise ours right to take part in political activities, even though we are a migrant community. Likewise we take pride in Bangladesh having a democratic system in place that is designed to allow for freedom of expression and the ability to bring leaders to account for the good of the country. However, the recent incidents sanctioned by the government against opposition political organizations, questions the entire validity and legitimacy of democracy in Bangladesh.

We hope and pray that this message does not fall on deaf ears and ask that you take suitable steps to reverse and bring an end to the ongoing persecution and torture of the opposition political groups and restore a healthy environment in the country's educational institutions. We hereby earnestly request you to extend your helping hand to the peaceful and democracy-loving people of Bangladesh, so as to ensure that your government:

1. Take necessary steps to stop all extra-judicial arrests and killings immediately, restore the rule of law and protect all human rights including the democratic rights of the opposition parties;

2. Ensure democratic activities are conducted with political representation and pluralism, and to stop politically motivated arrests and killing of the opposition activists.

3. Release all opposition leaders and political prisoners of conscience;

4. Allow a free and unfettered media;

Sincerely,

\section{Bangladeshi origin UK citizens}

The above petition can be accessed in the internet through: http://www.petitiononline.com/ u080710k/. I accessed it in the internet on 11 July 2010).

The AL government came to power through the 6th January 2009 national election which gave a very questionable result. It could not come to power unless the army government at that time helped them to come to power. This government is trying to establish an autocratic and dictatorial rule to oppress the opposition party leaders. Within one year and a half, the whole administration of the country has been fully taken under the control of the AL government by appointing and promoting the AL supporters in the administration sectors. During the appointment and promotion processes, the officers were directly asked whether they belonged to the $\mathrm{AL}$ and whether they would help this government to be in power for a long time. The judiciary including the higher courts are also now under the full control of the AL government. In May 2010, the AL government has appointed 10 justices in the Supreme Court of Bangladesh from the hardcore Awami League government supporter senior lawyers (Rahman, 2010). Thus, the possibility of getting a fair and impartial trial and justice from the judiciary of Bangladesh is very slim, indeed, if the case is related to the opposition political parties.

As was mentioned in the above paragraph, the AL government has a full control of the judiciary and the police force in Bangladesh. In political cases, it is not possible to get justice. The AL government has withdrawn more than 6000 (six thousand) corruption and criminal cases against its top leaders and supporters but thousands of cases against the opposition party leaders and supporters are still under trial. This has a very damaging political effect to the country as it is seen to be encouraging the AL and its branch student organization 'Satro League' to indulge in more and more subversive and destructive activities. Recently, the Prime Minister and the Home Minister of Bangladesh openly said that they are unable to control the destructive and oppressive activities of the AL and Satro League (Siddiqui, Rezwan, 23 July, 2010). They are beating up and killing the opposition leaders 
extra-judicially while the AL government is silent and thus gives the solid unquestionable impression that it is in fact supportive of their subversive and oppressive activities (Rahman, 2010).

As said earlier on 13 June 2010, another two top Jamaat leaders, Assistant Secretary General Kamaruzzaman and Assistant Secretary General Abdul Kader Mollah were arrested from the High Court premises of Bangladesh. Both leaders got order from the High Court requiring the AL government and police not to harass and arrest them until their bail petition is heard and settled by the High court, but the police overruled the High court order. The police arrested them under the order of the AL government. It is a contempt of court and gross violation of human and democratic rights and equal protection of law. Assistant Secretary General Mr. Kamaruzzaman said this government has no soil under its foot, people have abandoned them because they are arresting and oppressing the opposition party leaders when the people in the country are severely suffering from acute hot weather while government has failed to provide adequate supply of electricity, water and gas to them for the last one and a half year rule of the AL government. This just goes to show to the world the type of government Bangladesh is now being ruled by people who have no proper knowledge of running a country, much less sustaining a vibrant progressive government with its ever sagging economy.

So, far five top Jamaat leaders have been arrested and taken on police remand for 16 days for each of them and they are being oppressed during remand. All cases against them were false and politically motivated and oppressively executed. The court gave them bail, but the AL government overruled the court's decision, hence this government is putting pressure on the judiciary and disallows the judiciary to act impartially. In such a situation the intervention from the international political organizations and developed countries such as UNO, European Union, USA, UK, Security Council etc is very highly needed. (The Daily Naya Digonta, 2010).

The AL has planned to try the arrested top Jamaat leaders for war crimes which were committed in 1971 by 195 Pakistani army officers and soldiers when no Jamaat leader was convicted at that time. The UK State Minister for International Development Alan Duncan said on 14 July 2010 that the trial of 1971 war criminals should be conducted fairly through a proper judicial process.

Duncan said, "The government must ensure that the judgment on war crimes trial is not politically motivated." He said this while addressing a press conference jointly organized by the British High Commission in Dhaka and UK Department for International Development (DFID) at the city's Lake Shore Hotel (Duncan, 2010).

It is widely known to the people of Bangladesh that the AL is arresting the top leaders of Jamaat, one of the largest political party in Bangladesh with the intention to crack down on the party's movement against the government. The AL government has totally failed to solve the unemployment problem; electricity, gas, water shortage problem; rising of price of daily necessities, etc. The AL government has also conducted a very inhuman procedure to oppress the Jamaat leaders during remand to force them to say something which they did not do, for example, they were involved in killing some people in Pallabi, burning cars during strike, killing and raping people during the liberation war in 1971. Such an attempt would be a gross violation of human right and the democracy of the country. It is also illegal and a violation of the Penal Code and Code of Criminal Procedure in Bangladesh.

From the statement of Mr. Duncan it is clear that there is a possibility that the AL government will deal with the 1971 war crime issues politically and it may oppress the accused during the remand period as the norm. He also expressed his fear that the war crimes trial may not be fair and impartial. It is widely known that Jamaat leaders will be tried under the War Crimes Tribunal Act 1973 (the 1973 Act) which is not of international standard. It is in fact an illegal law in Bangladesh and of no international level as it contradicts many fundamental rights and provisions provided in the holy Constitution of Bangladesh. It has provisions which state that hearsay evidence and newspaper evidence in 1971 can be used to find an accused guilty of an offence, although they are not admissible under the Evidence Act of Bangladesh. The 1973 Act makes the trial court equivalent to the High Court and the accused will not get any right to appeal to the High Court and the Supreme Court of Bangladesh if the first trial court finds them guilty of war crimes, murder, rape etc. This is a total violation of human and political rights provided in the Universal Declaration of Human Rights (UN) and International Covenant on Civil and Political Rights (UN). The persons who framed this law must have been drop-outs from the law school.

\section{Conclusion}

Although the AL government arrested the top Jamaat leaders to institute against them for 'hurting the religious sentiment' of Muslims in Bangladesh, but that was not the main objective of the government. As a matter of fact, the AL government wants to put on trial the top Jamaat leaders for the so called war crimes that happened in 1971. In fact in 1973, the then Prime Minister of Bangladesh identified only 195 war criminals after investigation and all of them were Pakistani army officers and soldiers. Later through a tripartite agreement 
between the Bangladesh-India-Pakistan, all these 195 war criminals were granted amnesty and they were sent back to Pakistan. After that the war crimes issue was settled in 1973 (Tripartite agreement 1974; the Simla agreement; Tipu, 28 March 2010). It is most abhorrent that out of anger and political revenge, the AL government has again opened the settled war crimes issue after 40 years of the independence of Bangladesh and filed suit against the top leaders of Jamaat. The AL government will start the trial of the Jamaat leaders very soon as the War Crimes Tribunal has already been formed (RTNN, 25 March 2010; Serajul and Saidul, 1 April 2010; Saidul and Serajul, April 2010).

The Jamaat leaders were not involved in war crimes and they are not afraid of the trial. They are afraid of the government that it will not hold a fair and impartial trial because the AL government has the criminal intention to hang the top Jamaat leaders with false and fabricated evidences after which it will ban the party to kill its arch rival forever. This intention of the $\mathrm{AL}$ government is known to the people of Bangladesh. Another frightening issue is that the law under which the Jamaat leaders will be tried is inhuman and does not conform to the international standard war crimes law in the civilized world (David, 15 March 2010; Sarker, 28 March 2010; Abdul Kader, 28 March 2010; Daily Sangram, 23March 2010). In this situation, the world human rights organizations have duties to put pressure on the AL government to follow the international war crimes law standard and procedure to try the accused for war crimes that happened in 1971, 40 years ago from now. They can also ask the AL government to try the criminals of 1971 war under the Penal Code of Bangladesh which conforms to the international standard criminal law as it provides all the fundamental rights guaranteed in the Constitution of Bangladesh such as right to appeal to superior courts, international standard evidence, fair and impartial procedure of trial etc.

It is also a big question why the AL government did not try Jamaat leaders during the past 40 years. An important fact which is known to the people of Bangladesh is that there is no single criminal case that has been filed in any police station in Bangladesh against any Jamaat leaders for their alleged involvement in murder, rape, looting and arson in 1971 during the last 40 years. In 1973, the then Prime Minister of Bangladesh also could not prove the alleged involvement of Jamaat to the above mentioned crimes through investigation. The investigation report at that time stated that no Jamaat leaders were involved in the above heinous criminal offences. False and fabricated murder, rape, looting and arson cases are filed against Jamaat leaders only in 2008 and 2009 during AL rule after 40 years of the incidence. So, these cases are clearly politically motivated and a clear case of oppression of the Jamaat leaders.

Another important fact which is well-known to the people of Bangladesh is that there were other six political parties who opposed the separation of Bangladesh in 1971 and many of the political leaders from those political parties who opposed the separation of Bangladesh in 1971 are leaders of the AL. In contrast to the above narration, the AL government is not suing them in court mainly because it is only suing the top Jamaat leaders out of malice, revenge and vindictive criminal intention. This proves that the AL government is taking the issue fully politically to destroy a popular democratically registered, elected and established political party in Bangladesh. This means that the arrest and trial of the top Jamaat leaders are totally politically motivated, vengefully executed, vindictively manipulated with cruel and oppressive procedures of confession on fictitious information in violation of human and democratic rights. All these uncivilized and unislamic activities point to the grand formation of a glaring frame-up conspiracy to destroy or ban this party (Jamaat) once and for all. It is well known to the people of Bangladesh that a close neighboring country of Bangladesh has pertinent interest in Bangladesh and has good relation with the present AL government. This neighboring country has been deemed to issue instructions to the AL government on how to destroy Jamaat, a popular democratic party while the AL government is faithfully implementing those instructions of the conspiring neighboring country to destroy its very own national interest, national peace and harmony and national development in Bangladesh. Such people are fit to be called political cadavers of subhuman species.

The Secretary General of Jamaat in Bangladesh has been given another 3 days of police remand after the 16 days successive police remand has been completed (The New Age, 16 July, 2010). Jamaat President Nizami has been on police remand for 21 days continuously, and it is to be fully noted that he is an old man of more than 70 years of age and he was mentally tortured during the police remand (The Daily Sangram, 20 July, 2010; The Daily New Age, 20 July, 2010). As of August 6, all top Jamaat leaders have been taken on 22 days consecutive police remand and they are not allowed to sleep whole night as interrogation is conducted at night only. There is a possibility that the AL government will continue to take Jamaat leaders on remand on so many new, false and fabricated cases. This form of unheard of interrogation system is highly inhuman in any civilized country to allow police remand for so many days continuously against the national leaders, especially those who are very old and suffer many complicated diseases. Those who perpetrate these heinous barbaric acts of human sufferance 
are in reality political sadists who gain tremendous pleasure in knowing that their political rivals are being tortured to the extent that they may regret the day they joined the Jamaat party. The Jamaat Secretary General, Mujahid was a reputed Walfare Minister between 2001-2006, who had vehemently mentioned that all the charges were false and politically motivated and at the very worst just mere hearsay specifically created by those who had the morbid intention of the government to destroy the opposition parties and to establish only one party with a secular rule in Bangladesh.

As mentioned earlier, on 18 July 2010 two more Jamaat top leaders had been arrested from the High Court premises and they had been on police remand for 16 consecutive days. They are Assistant Secretary General Kamaruzaman and Assistant Secretary General Abdul Kader Molla. These two leaders had been on police remand on the same fabricated cases which were implicated with the Jamaat leaders, Nizami, Saydee and Mujahid. All the five top Jamaat leaders are now very sick due to cruel treatment during their remand period as the remand place is not hygienic at all where the rooms are very hot with no fans provided. It is to be sanely noted that the accused are not allowed to sleep the whole night as they are interrogated only at night and for the whole night. During the police remand, this is the type of mental and physical torture that has been allotted to these respected national leaders who had contributed their best during the tenure of their high public office. No sane logical and civilized words can describe the lowness of mentality of these so called Bangladeshi sadistic brutes that have no regards and respect for those who had once been in power and gracefully served the public domain. The reason for this brutal atrocity is mainly because these brutes had never before tasted the glory of power and as sadistic brutes of low mentality, they glorify themselves in performing this ignominiously despicable subhuman behavior on such honorable political leaders who were in power and senior ministers in the last government of 2001-2006.

The accused were not allowed to consult medical doctors for medical check up before and after remand although the High Court of Bangladesh ordered the police department to do so. On 15 July, 2010, the High Court of Bangladesh ordered in a petition case that the police must allow medical check ups to be conducted on the national leaders before and after their remand, but the police were not allowed by the ruling government to follow the High Court's order, thus the police is being openly blamed for committing contempt of court. The higher courts are now helpless and powerless as the AL government fully control the judiciary in Bangladesh. The respected national leaders were not allowed to sleep at night during remand and they were not given any pillow to sleep upon (Sangram, 16 July, 2010; Saydee and Mujahid, 2010). One shudders to think how these accused national leaders were able to survive this inhuman ordeal under gross violation of human rights and comprehensive political persecution of the Bangladeshi national opposition leaders. Such kind of behavior by a democratic government in Bangladesh is very criminal in nature and such a cruel treatment on the opposition party leaders can never ensure peace, security, development and human rights and the wellbeing of the oppressed citizens.

As of 4 August, 2010 the AL government has so far arrested more than 4000 Jamaat leaders including five top central leaders from all over the country and put them on police remand on false and fabricated cases. The AL government has already cancelled the license of TV Chanel One and Daily Amerdesh Newspaper for announcing and writing on the oppressive activities of the AL government on the opposition party leaders and committing gross violation of human rights. The AL government has warned against all national newspapers and private TV channels not to publish or broadcast anything against the government. If they do not follow the government's order, their permit will be immediately cancelled and their premises will be locked. The AL government has also ordered the police department not to allow any meeting or rally by the Jamaat leaders and supporters. The police have been tacitly encouraged by the ruling party to beat their prisoners of the opposition party severely, injure them and arrest them whenever they attempt to have any meeting or gathering in protest of arrest of their central top five leaders on false charges. This is a conspiracy of the government to destroy a popular political party so that it can be in power for a long time without opposition against its unlawful and criminal activities which goes against democracy, national interest and national security. If such socio-political activities by the ruling party in Bangladesh continue, this country will never be able to progress economically and socially and the Bangaladeshi as a whole will severely lose their identity and pride in the sphere of global, international, social as well as economic transactions in their home country.

It is very worrying that $\mathrm{AL}$ government after coming to power in January 2009 has fully subdued the three important administrative branches in Bangladesh such as Army, police and judiciary. All anti-Awami League and pro-Islamic top Army officers have been dismissed or forced to retire. In Pilkhana tragedy more than 70 top army officers were killed in cooperation with the present government as mentioned in the army led independent investigation committee report. The former police IGP has been changed and all pro-Islamic and pro-BNP police 
officers have been made inactive to fully control the police department and to use them against opposition parties to operate cruelty and oppression on them. Last but not least, three Justices have been appointed in the Appellate Division of the Supreme Court and ten judges in the High Court Division of the Supreme Court of Bangladesh who are hardcore supporters of AL government and fully willing to manipulate decision if dictated by the government. This is well-planned to fully tame the judiciary to AL government so that judiciary is not an headache to AL to accomplish its one party rule by reviving the 1972 Constitution and it has already been done by AL government through the Supreme Court of Bangladesh on 27 July 2010 (Reyman, 27 July; Ilias, 1 August, 2010). Therefore, the lower courts as well as the superior courts are fully following the instructions and orders of AL government which is to destroy the independent and impartial judicial and justice system in Bangladesh. Thus, in Bangladesh there is no hope of getting fair and impartial trial and justice in criminal or civil cases where government is a party. Such an attempt of AL government to fully tame the three important administrative and law enforcing agencies tantamount to total violation of independence of judiciary and ruining the democracy in Bangladesh. In fact, AL government is accomplishing a long-cherished criminal blueprint to establishing one party rule (autocratic rule) in Bangladesh which was also done by the present Prime Minister's father Sheikh Mujibur Rahman in 1974-1975 and the consequence was very sad. So, the daughter should have taken lesson from that sad news.

In view of the perpetual persecution and inhuman treatment of the past national leaders which no country has ever performed, these political brutes of low mentality have earned the citizens' silent anger which is translated into fervent prayers for the rapid downfall of the cruel ruling party. However, these brutes of low mentality have been literally, if not spiritually, blind because they should have seen the signs sent down by Allah through the recent floods, hurricanes, shortage of food, occurrence of infectious diseases all of which are the signs that Allah had sent down to them but they are just like the long gone Pharaohs of Egypt that still maintain that they will be in power forever. The day will soon come when their tower of power will come crashing down on them and you can then see them running for dear life with their tails between their legs.

These same brutes of low mentality have no personal pride in themselves because they never care about their unemployed citizens who have gone abroad seeking greener pastures because back home there is no pasture at all. These oversea Bangladeshis are the ones that really carry the torch of the original respectable Bangladeshi because they demonstrate good public behaviour, tolerant to their host country's laws and order, very sociable and easy to deal with in terms of job performance. However, as a rule of natural cause and effect as laid down by Allah the Almighty, those who had performed their deeds will be rewarded by Him in equal amount equitably and these very brutes who had executed such heinous deeds will definitely suffer the terrible psychological kickback as a direct result of what they had unreasonably and unmercifully executed on others.

\section{Acknowledgement}

I am grateful to anonymous reviewers for their valuable comments on my paper which have helped me a lot to revise the paper to upgrade its standard.

\section{References}

Abdul Kader. (2010). Bengali Hero Kader Siddiqui in TV Interview: AL government is not ready for war crimes trial; fair and international standard trial needed. The Daily Sangram, 25 March, 2010. [Online] Available: http://www.dailysangram.com/news_details.php?news_id=27905 (25.03.2010).

Abu Hurairah. (2010). Prophet Muhammad is the last prophet. Sahih Bukhari, Vol. 4, Chapter 56, Hadis no. 661.

Akbar, Ali. (2010). Politics is now moving towards anarchy. The Daily Samokal, 10 July, 2010, [Online] Available: http://www.sonarbangladesh.com/newsdetails.php?ID=5875 (10.07.2010).

Amnesty International (AI). (2010). AI criticizes security forces' excess during peaceful strike. The Daily New Nation, 3 July 2010. [Online] Available: http://nation.ittefaq.com/issues/2010/ 07/03/ (03.07.2010).

Askar. (2006). What prophets were slain by Jews during the time of Moses? [Online] Available: http://answers.yahoo.com/question/index?qid=20061227143442AAvlCYr (23.07.2010).

BJI (Bangladesh Jamaat-e-Islami). (2008). War Crimes Law and the Constitution of Bangladesh. Dhaka: Central Publicity Department, BJI.

Daily Sangram. (2010). TV Interview: AL Government is not ready for war criminal trial, it is necessary to have fair and international standard trial. The Daily Sangram, 23 March 2010. [Online] Available: http://www.dailysangram.com/news_details.php?ness_id=27905 (25.03.2010). 
David, Bergman. (2010). War Crimes Law Falls Short. bdnews24.com. [Online] Available: http://www.bdnews24.com/details.php?id=155832\&cid=2 (20.03.2010).

Delwar. (2010). BNP to support Jamaat programs. The Daily Star, July 2, 2010. [Online] Available: http://www.thedailystar.net/newDesign/latest_news.php?nid=24541 (2 July, 2010).

Duncan, A. (2010). War crimes trial must not be politically motivated. The Daily Star, 15 July, 2010. [Online] Available: http://www.thedailystar.net/newDesign/news-details.php?nid= 146784 (15.07.2010).

Ilias, Najnin. Arrest of Jamaat leaders, criminal suit against Sadeq Hossain Khoka and vandalism in strike. The Daily Sonar Bangladesh, 9 July, 2010. [Online] Available: http://www.sonarbangladesh.com/article.php?ID=3093 (09.07.2010).

Ilias, Najnin, Talkshow on 'going back to 1972 constitution of Bangladesh. The Daily Sonar Bangladesh, 1 August, 2010.

Kalz, Jochen. Which prophets did the Jews kill? [Online] Available: http://www.answering-islam.org/Quran/contra/Jews_killed_prophets.html (23.07.2010).

Killing of prophets. Bible: Luke 3:19-20; Mathew 14: 3-12, 21: 23-27; Al-Quran: 2:61, 91; 3: 112.

Naya diganta. (2010). Jamaat leader Kamaruzzaman and Abdul Kader Molla have been arrested from the High Court premises. The Daily Nayadiganta, 14 July, 2010. [Online] Available: http:www.sonarbangladesh. com/news_details.php?ID=5969 (14.07.2010).

New Age Report. (2010). The Daily New Age, 1 July, 2010. [Online] Available: http://www.newgebd.com/ 2010/jul/01/ front.html (01.07.2010).

New Age. (2010). The Daily New Age, 16 July, 2010. [Online] Available: http://www.newagebd.com/ 2010/jul/16/front.html (16.07.2010).

New Nation. (2010). Conspiracy against Jamaat as it supports BNP. The Daily New Nation, 3 July, 2010. [Online] Available: http://nation.ittefaq.com/issues/2010/07/03/news0999.htm (03.07.2010).

Petition to Prime Minister. (2010). [Online] Available: http://www.petitiononline.com/u080710k/ (11 July 2010).

Police report. (2010). Police said: Mujahid, Saydee deny link to strike violence. The Daily Star, 2 July, 2010.

[Online] Available: http://www.thedailystar.net/newDesign/latest_news.php? nid=24551 (02.07.2010).

Rahman, Siraj. (2010). The oppression on Mahmudur Rahman by AL government is frightening sing for the nation. The Daily Nayadigonta, 15 June, 2010. [Online] Available: http://www.dailynayadgonta.com/2010/06/15/ fullnews.asp?News_ID=2168448sec=6 (15.06.2010).

Rehman, T.S. (2010). Some statements on the Amendment of the Constitution of Bangladesh. The Daily Sonar Bangladesh, 27 July 2010. [Online] Available: http:www.sonarbangladesh.com/articles/TareqShamsurRahman, (01.08.2010).

RTNN. (2010). Announcement of 6 member Investigation Committee for War Crimes Tribunal in Bangladesh. [Online] Available: http://www.rtnn.net/details.php?id=22974\&p=1\&s=3, (25.03.2010).

Sangram. (2010). Arrest of Three Top Jmaat Leaders and Taking them to Police Remand. The Daily Sangram, 1 July, 2010. [Online] Available: http://www.dailysangram.com/news.details.php?news_id $=33790$ (01.07.2010).

Sangram. (2010). Mujahid and Saydee again for three days police remand. The Daily Sangram, 16 July, 2010. [Online] Available: http://www.dailysangram.com/news_details.php? news_id=34732 (16.07.2010).

Sarker, Barrister Jamiruddin. (2010). Barrister Jamiruddin Sarker to the journalists: to try war criminals with an intention to weaken the opposition parties, would not be acceptable and credible. [Online] Available: http://www.dailysangram.com/news_details.php?news_id=28071 (28.03.2010).

Saydee and Mujahid. (2010). We could not sleep nine nights. Daily Nayadigonta, 11 July, 2010. [Online] Available: http://www.sonarbangladesh.com/newsdetails.php?ID=5900.

Serajul Islam and Saidul Islam. (2010). War Crimes Tribunal in Bangladesh: A Miscarriage of Justice. JUST Commentary: International Movement for a Just World, Vol. 10(4), April 2010, at p. 3.

Serajul Islam, and Saidul Islam. (2010). War Crimes Tribunal in Bangladesh: A Contested Move. [Online] Available: http://www.sonarbangladesh.com/article.php?ID=2296 (27 April 2010).

Siddiqui, Rezwan. (2010). Does the Awami League need to prevent 'human chain' by opposition? The Daily Sonar Bangladesh, 10 July 2010. [Online] Available: http://www.sonarbangladesh.com/article.php?ID=3109. 
Siddiqui, Rezwan. (2010). Give proper attention to administer the country. The Daily Nayadiganta, 23 July, 2010; the Daily Sonar Bangladesh, 23 July, 2010. [Online] Available: http://www.sonarbangladesh. com/articles/DrRezwanSiddiqui (24.07.2010).

Star report. (2010). BNP agitates under cop vigil. The Daily Star, 8 July, 2010. [Online] Available: http://www.thedailystar.net/newDesign/news-details.php?nid=145832 (09.07.2010).

The Simla Agreement, $2^{\text {nd }}$ July 1972.

Tipu, Faheh Ali. (2010). The propaganda and reality of war crimes: purely politically motivated trial. [Online] Available: http://www.dailysangram.com/news_details.php?news_id=28073 (28.03.2010).

Tripartite agreement. (1974). Bangladesh-India-Pakistan Agreement 1974. It was signed in New Delhi on April 9 , 1974.

\section{Statutes}

Code of Criminal Procedure (Bangaldesh)

Evidence Act (Bangladesh)

International Covenant on Civil and Political Rights (UN).

Penal Code (Bangladesh)

Universal Declaration of Human Rights (UN)

War Crimes Tribunal Act 1973 (Bangladesh)

\section{Court cases}

Professor Golam Azam Vs. The Government of Bangladesh [1994] 45 Dhaka Law Report, High Court Division, page 433.

Sayed Abul Ala Mawdudi and Others Vs. The Government of Pakistan and Others (1964) 17 Dhaka Law Report, Supreme Court, Page 209.

The Government of Bangladesh Vs. Proferssor Golam Azam, [1995] 46 Dhaka Law Report, Appellate Division, page 192 . 